UDC 821.111.09'06

DOI https://doi.org/10.32838/2710-4656/2021.4-3/08

Dyndarenko O. A.

Petro Mohyla Black Sea National University

\title{
R. KIPLING: A COSMOPOLITAN OR AN "IMPERIAL BARD" IN POETRY AND PROSE?
}

The article deals with the investigation of the role of the Eastern and Western philosophic ideas in both the writer's career and the heritage of the English postcolonial literature. For the first time in the history of the modern Ukrainian Literary Studies the link between the novel "Kim" and a number of short stories in creating the image of India has been made to reach translation objectives. As $R$. Kipling's narratives often involve the journalist-narrator as the narrative correspondent: the man-on-the-spot with information for a reading audience, whose narrative persona is not always objective or distanced from the events that unfold, so, could we relate it to the writer himself, as the figures are akin in journalistic mediation and interpretation of news. In "The Return of Imray" and "The Mark of the Beast" his presence serves to verify the authenticity of strange affairs and to mediate their experience for readers. In "The Strange Ride" and "The Man Who Would Be King" he comes across unusual incidents, which he (re)stages for readers' benefit. In "The City of Dreadful Night" and "To be Filed For Reference" his nightly exploration of parts of the native city yield tableaus of native and colonial lives. In this respect, his narrator is often a petty pilferer or loafer, either stealing bits of other people's lives or stories of their lives to fashion a novel story which gives new perspectives for the development of the reading-translation strategies in studying $R$. Kipling 's narratives.

The advanced ideas in culture-related issues about India, gender questions and tendencies of cross- and multi-culturalism provide changing the perception of $R$. Kipling's literary heritage as orientalist into a cosmopolitan one. In our attempt to compare the main issues of Russian and Ukrainian translation, we try to propose possible perspectives of further study of the writer's literary works in the content of the post-colonial studies with the gradual change of the traditional points of view on the author, imposed by Edward Said and Sara Suleri to the mode While it is dangerous to equate the frame-narrator with Kipling, there are passages in "The Man Who Would Be King" which are lifted directly from Kipling's record of his own travel experiences in the Princely States. On assignment for the Pioneer in Rajasthan (which resulted in "Letters of Marque"), he describes himself in a letter to his cousin Margaret Burne-Jones in similar terms as his framenarrator. He describes himself as" having railed and rode and drove and, tramped and slept in King's palaces or under the stars with natives in desolate wayside stations". Diverse experiences contribute to the narrator's authority; "wonderful and awful things" experienced during the journey become fodder for his writing., unbiased and impartial one, - all this gives new objectives to understanding and translating the content of the writer's literary works of this period.

Key words: a cosmopolitan, "iron Rudyard", "Bard of Impire", Indian and Anglo-Indian society, orientalism, gender problem, cross- and multi-cultural tendencies, the British Empire, postcolonial literature.

Stating the problem. Through centuries we have got used to describing Kipling as the imperial storyteller or the preeminent bard of the British Empire, but we also have a goal of our investigation to show an alternative portrait of a cosmopolitan R. Kipling, the one indebted more to journalism and its quest for novelty, gender equality and adventure, as the man-on-the-spot. Involving the up-to-date research of the translation objectives in studying R. Kipling's literary heritage both by the Ukrainian and Russian experts, we'll try to enforce the unbiased perception of the author as the one with cross- and multi-cultural ideas of relation between Indian and Anglo-Indian society and creating the image of India as eternal in its philosophy and changing in its everyday life.

Analysis of the latest researches and publications. The numerous renowned reaserchers of the postcolonial critics, such as: Homi Bhabha, Sara Suleri, H. Tiffin, Edward Said, M. Pratt, A. Lawson, P. Brantlinger, B.Ashcroft, G. Griffiths, W. Harris, J. Clifford, Gobind, J. Rignall and others studied the heritage of R.Kipling, but there are still no profound works on the topic of our research, particularly from the point of view of comparing 
and studying the genesisof the ideas of the English writer of the first part of the twentieth century R. Kipling as for the role of the East and the West in portraying the image of India. There are only random critical comments, proposed by M. Strikha, L. Herasymchuk as representatives of Ukrainian Literary Studies School.

Outlining the aspects of the problem which haven't been solved. The scientific novelty of our research implies the restoration of R. Kipling's reputation of the cosmopolitan author through the impartial, objective and unbiased study of his literary heritage, especially of the novel "Kim" in the context of the postcolonial discourse, oriental studies, gender problem, and the tendencies of cross- and multi-culturalism. The theoretical importance of our research is that it gives opportunity to the deeper further study of the literary heritage of R. Kipling changing the orientalist view upon him. We also simultaneously research and compare the image of India in the novel Kim and other literary works by R. Kipling.

The aim of the article. The main goal of the article is to reach the new translation objectives and perspectives in studying the restored heritage of R. Kipling's novels and short stories by the Ukrainian and Russian experts and critics and in the first place thanks to the reconsideration of the imperial story-teller's image, transformed into the journalist-reporter - a cosmopolitan one.

Representation of the main points of the research. Once E. Said mentioned that "every work of culture represents a certain perception of the momentum, and we have to correlate it with the different ponts of view it caused later" [1, p. 47]. So, we'll try to prove that R. Kipling managed to create the image of India with its national cultural peculiarities of language, nature, history, religion and philosophy, which are eternal, independent from the British rule.

When dealing with the novel "Kim", we associate it with Kim, involved in "the Great Game" or the British Intelligence Service, and Teshu Lama, who inspires Kim to seek for "the Healing or the Arrow River". Kim is "the little friend for the whole world", trying to get free from "the Great Wheel" in the East or the life burden in the West. Connection between Kim, who turned into "chela", the lama's apprentice, following "the Way, the Gates of Learning, is, for sure, the central, allegorically conveying the dialogue between the East and the West. Kim is indowed with the art of reincarnation on the level of "dasa" (a saint in the transcendental bhuddist philosophy) and feels at ease in any environ. He easily changes systems of values, religions, speaking and understanding any local languages and dialects (Bengali, Hindu, Urdu, Pathan, Saddhu). Numerous dialects and styles of speaking are given in the novel, phrases, understood to everyone: "Om mane pud me hum!" "Hai mai!" "Allah kerim!" - "as the God's prayer is universal and appeals to the world", as lama thought [2, p. 145].

The legend about "the Healing or the Arrow River" is central in the novel. Lama's mission, as a guru, is to become a saint, having gone through the trials and ordeals to the Healing River together with his "chela", Kim, to reach the healing source of the spititual life of every lama. To get rid of the Great Wheel, with its main symbols and man's weakest sides and the gravest sins in Buddhism: Wild Boar (Ignorance), Snake (Anger) and Dove (Lust) and to free his own soul and the chela's one.

The holy Ganges river helps to get rid of the Great Wheel, so during the most popular religious holidays, the clay statues of the God after the prayer are ceremonially carried to the river and thrown into it! Indians also believe that the healing Ganges waters can help them get rid of the diseases and sins during the ritual bathing on the Holy Krishna's birthday. There is certain analogy between the Bible legend of Christ's childhood in Nazareth, a Palestinian city, and Gokul, a secure place, where Krishna was brought by the shepherd Nanda, living there among the shepherds, similar to Jesus, who lived in Nazareth in a carpenter's family. There is even the legend in the text about the flood myth, based on the Indian parable, with the same origin, that the Christian one. The myth of Noah's Ark reminds the myth of the Ark of the Lord Manu.

Nature is assential in the content of Indian philosophy and namely through the constantmeditation with Nature one can reach the spirit of excellence. The Indian proverb says: "Who goes to the hills, goes to his mother" and the saying follows: "one chooses the hills, and the other is native to the sea" [2, p. 159].

The author can't help admiring the the unprecedented beauty of the Indian nature on every page of the novel. Using all possible types of "tropes" of fiction style, R. Kipling describes the plains, hills, forests, valleys of the rare beauty - mystical and arcane, "worshipped by the people as devils", and the plains "treated as holy men" with the "eternal snow" of Thibeth, where Nature is so fascinating, that it could only be a temple for the holy gods, but not for the sinful people: "Suerly, the Gods live here! This is no place for men!" [2, p. 170]. For Teshu Lama India is the place of the endless sea, emerald green 
forests and "diamond air", the place where, according to the proverb, “...plains-bred and plains-fed..."; along which he endlessly wanders as a lonely loafer, confessing that "the knife-edged breezes which had cut the years off my shoulders" remembering that "forests and valleys took to their bosom" numerous homeless Sakhibs [2, p. 182].

Concluding on the topic of studying the use of literary tropes in creating the image of rel India with its natural colouring and culture and religious peculiarities in the novel "Kim", we can state that with the help of language realia, tropes, numerous substantial names of folklore, philosophical and mythological knowledge of the writer, R. Kipling managed to create the image of India with its eternal pre-British past, which has been preserved and valued up to now. Thus, we have to change our traditional view of the author and his literary heritage, from the typical orientalist one of the postcolonial critics into the avangard cosmopolitan perception.

The phenomenon of R. Kipling is still disputable and involes a number of experts, according to Maksym Strikha, a well-known Ukrainian literary critic. Endless attempts to explain his popularity with his renowned notorious past, love of exotics, and political engagement, won't in the least help us approach the level of understanding the literary phenomenon called "Rudyard Kipling" (or "the Iron Rudyard" - as he was called by the friends and the enemies and opponents, putting quite different pretext into the term. R. Kipling embodies one of the greatest men of letters, with his unique style or writing an $\mathrm{d}$ un precedented talent, though being quite an ordinary person from the first sight, whose literary career and heritage can be judged from their unique, peronal laws and rules, peculiarities and atmosphere. T. S. Eliot was the first to do this in his foreword to the Collection of Kipling's Poetry, he has arranged and selected. T. S. Eliot mentions that there were many poets aspired to create potry, but all of them could be easily forgotten, with the exception of the satirical ones. Whilst R. Kipling created real poetry, though not asprired to copose it at the beginning. So, what T. S. Eliot stresses as peculiar, is this desire to become "the author of ballads ... T. S. Eliot is simultaneously broadening and expanding the meaning of the word "ballad". Events are focused more in the narrative ballads, the aim of which is to cause certain emotions. Poetry, lyrics is a secondary matter in them, usually subconscious, and the shape of such ballads - short rhymed stanzas. The reader's attention is concentrated on the events and characters, the content of the ballad must be simple to be easily understood by the audience. When the ballad is dramatized, the next presentation enforces the effect of the previous one, dut the complete understanding ought to be reached directly after the first one. The metric shape must be simple, the one not attracting much attention, though repetition and refrain could add the effect of a spell to the ballad... Ballads are prevailingly read out-loud to reach the best effect. But still this simple form and shape is combined with the fabulous talent of the man of letters, eloquence, a unique use of phrases and rythm. Ballad stanzas must be shorter, the scheme of rhythm should be rather simplified in order to be quickly apprehended, the refrain promotes repetition, where the possible number of rhythmical variations is restricted.

M. Strikha considers, that "the phenomenon of R. Kipling is that he manages to create a great number of forms and shapes for his ballads: each of which is so perfect and best suits the content and the atmosphere of the literary work. At the same time rhyming is not so regular: monotonous rhythm is present, where it is required, though there is a number of deviations from the classical metric shape and form" [3, c. 6].

Unfortunately, these positive remarks about the talent of thre writer were made posthumously. The reputation of R. Kipling as a writer had started to decline long before this. If the first books by R. Kipling were criticized from the aesthetical critical point of view, at the beginning of the twentieth century more important reasons for criticizing and blaming the author appeared. Humanity entered the new epoch of radical social, political and religious transformations, on the background of which R. Kipling, with his strong belief in the unique historical mission of Great Britain looked like an anachronism. The intellectual elite of society avoided him, and for the young post-war avantgard poets, T.S. Eliot and Ezra Pound, with their complicated refined symbolism, Kipling, who spoke the common language for the millions, was percepted more as a "bard of imperialism" and the builder of Impire, similar to Cecil Rhodes.

This odious label was attached to R. Kipling, though one of its initiators, T.S. Eliot, contributed much to reviving the good literary reputation of the writer as a talented one. So we have to state clearly that R. Kipling, who lost his young son in 1915 in the battle of Loos, the one of Anglo-Boer war, during the WW I, and his little daughter, who died of grave illness, had never praised the suppression of the colonized countries and their people. For him "the white man's burden" first and foremost meant 
the honest, hard, painstaking work, sacrificing one's own life for the sake of other civilizations' and their people's well-being and educating. Sure, it was a naïve and mistaken point of view, but it doesn't justify the tendency of vulgurisation and persecuting the author's ideas in the time of cult and post-cult literary critics development.

The more these biased ideas about R. Kipling are opposed by the author in his famous "Ballad of East and West" with the first opening lines, which are translated as follows: "Захід є Захід, а Схід є Схід, і їм не зійтися вдвох, допоки Землю і Небеса на Суд не покличе Бог" - are usually wrongfully enterpreted and drawn away from the context as if the proof of the writer's idea of the eternal antagonism of the two civilizations and their systems of values, views, mentality and laws and customs. In fact, the whole ballad is a consequent refute of this thesis, the ardent hymn to the power of the human spirit, giving opportutinty to people to overcome any prejudices and give each other a helping hand. Taking into consideration that after these two most frequently cited stanzas follow the two completely the opposite, equivalent in translation: "Та Сходу i Заходу вже нема, границь нема поготів, як сильні стають лицем у лице, хоч вони з різних світів!" $[3$, c. 6$]$.

R. Kipling met the WW I with the chauvinistic poem-call "If". Later he would become aware of this useless blood-shed and would create the tragic, full of deep sarcasm "Epitaphs of war" and "Gethsemane". The idea of the ruthless, bloody, atrocious war and its role in the history of mankind at first was conveyed in the poem "On the March" - a poem, unexpectedly, against the author's plan, became one of the most powerful anti-war European poems.

After the WW I and the death of his beloved son in it, the writer had been living an isolated life, separated himself from the rest of the world and minimized his social environ. Until his last day of life he had been writing, but "the iron curtain" or "a stud wall of misunderstanding", which he had built himself, appeared between him and his readers and audience. Three years before his death he wrote in his short poem "The Appeal", addressing the future generations: "If I have given you delight by aught that I have done, let me lie quiet in that night which shall be yours anon: and for the little, little, span the dead are borne in mind, seek not to question other than the books I have behind." [6, p. 827] У вітчизняному перекладі звучить: "Наразі ж воскресять на мить мене чиїсь думки, то прошу не мене судить, а лиш мої книжки" [4, с. 2].
This appeal was left in vain, no one would listen to it. In 1936 England gave the last highest honour to R. Kipling, but not a single famous writer or a literary artist of the time attended the funeral at the Westminster Abbey. R. Kipling had died much earlier for them... And only 3 years before the death of "the Iron Rudyard" his younger successor, a political antagonist, the ardent supporter of "the left-wing", Vistan Hugh Auden had to agree: “За стрункі простять рядки Кіплінгу його думки...” [4, с. 2].

Years passed and "the Great British Impire" somehow faded away, as if so much praised by R. Kipling, and time, having hidden the shades of so much vivid political tendencies of the author's literary heritage, leaving to us the beautiful novels and poetry with their clear belief in the strong will and courage of a man, the ability to overcome any hardships on the way to achieve the highest life goal. The ideal of Kipling is the victory of the active creative spirit of man over stagnation and pessimism, which is mainly praised in the writer's poetry with a rare vigour and strength, is still valued and understood by every generation and in every epoch, with the writer's strong innate desire, moving us and touching our emotions so deeply with the author's poetry. No wonder that such famous translators of fiction as M. Lozynskiy, M. Humilyov, S. Marshak, K. Symonov popularized R. Kipling's talent, presenting more and more of his works in astonishing and fascinating interpretations.

Ukrainian interpretations of Kipling were less successful, unfortunately. There are only few attempts to translate his poetry by D. Palamarchuk, L. Solonko, Y. Svesrtiuk, V. Korotych, - but even mostly not officially published. There were reasons for this. The notoriety of the "Imperial Bard" was so strong, that it interfered with and excluded the author's literary works from the Ukrainian field of study and the audience of readers. Even the fairy tales from "the Jungle Book" were treated as "apology of imperialist hunt, about the human society, turned into the animal pack, where the single existing law is the right of a predator to a prey, with overall prevailing chaos, anarchy and disintergration, thirst for murderand fear of death, replace all the social norms of behaviour" [4, c.2].

Whilst in Moscow and Leningrad you could freely enjoy R. Kipling's literary works, giving the indisputable argument for this: "The literary heritage of Kipling is of a growing interest for our society as a perfect implementation of the unprecedented work of fiction, produced by our ideological enemy, the highest achievement 
of the western imperialist poetry", whereas in Kyiv, through the known conditions of publishing, such a preamble of Moscow and Leningrad origin completely excluded the possibility of printing and publishing Kipling's works in Ukraine [4, c. 2].

Only six decades later the first Kipling's works for children and a small collection for the adults appeared in Ukraine. And nowadays thanks to the radical transformations in our society, thus including into the literary circle dozens of literary names, previously condemned, we'll try to ruin one more myth the myth about R. Kipling as "a misanthrope", "the Imperial Bard", which ha always been only a myth, a prejudiced point of view, according to M. Strikha, whose point of view we support, as any educated person does.L. Herasymchuk, for example, stresses in his article "Непричесані думки", that there are permanent discussions about the interpretations of different authors, which burst out, who sell their talent to serve the degenerative or totalitarian government, justifies the crimes of his own state against other alien civilizations. He reminds us about Ezra Pound, who actively collaborated with the Italian fascist regime, and was tried and further convicted after the war by the American court of justice. And though his works are rather popular and talented, he is always blamed for his notorious Nazi loyalty. L. Herasymchuk remarks that a number of articles have been written in the Central Europe about the talented writers who were, like "double agents" and deceived their readers, trading their own talent to the repressive regimes in exchange for different preveleges, career of money. Though sometimes this question is avoided in the Central Europe, either is it in Ukraine, as L. Herasymchuk thinks, considering both native and foreign authors, mentioning R. Kipling as a betrayer either! He blames M. Srikha for praising the notoriously known writer, so popular in Russia only for his imperialist tendencies, characteristic of it as well, even the pronunciation of the name is in a Russian manner. L. Herasymchuk emphasizes that Kipling "was constantly praising British Imperialism, and convicting him by the former USSR and foreign critics could only be without irony. His literary talent was still widely popularized but it didn't deal with his political preferences... L. Herasymchuk also advices, remembering about the "postcolonial critics" to cite some of the Indian experts as for the values praised by the Nobel prize laureate" [4, c. 2].

We can't agree with L. Herasymchuk's point of view, as R. Kipling never collaborated with the eval government in favour of preveleges and even was avoided by it and lived in isolation, abandoned and forgot by the intellectual elite. He couldn't have praised any war, as he had lost his only son in the war! R. Kipling was a rare author with an unprecedented talent, sincere belief in the universal truth and justice, - which was treacherously used by the leaders of the Impire for their own profit and then blaming the author for all deadly sins and discrediting him in public, having understood that he was independent from their influence and would never betray his principles.

Volodymyr Chernyshenko successfully shared the idea of O. Zverev, expressed in the periodical edition of "Inosrannaya Literatura" («Иностранная литература»), № 1, 1992, and presented eleven Ukrainian translations of the poem "If", produced by the representatives of different Ukrainian literary schools of different epochs. They are worth comparing for an expert translator with five Russian translations, represented in O. Zverev's collection, produced by Lozinskiy, Kornilov, Gribanov, Sharapova and Marshak. The accuracy and value of translation is only growing more, when the translator shares the achievements of other experts in translation. For example, an outstanding Ukrainian translator Iryna Steshenko, whose literary works are neglected by our experts in the theory of translation, used German translations, working on her brilliant translations of Shakespeare; Palamarchuk used the heritage of Mykhaylov to interprete Byron's verses. For us, readers, the rich resulting translation is most valuable, while theoretitians and critics go into numerous details of the literary process of creating the work of art.

Conclusions and propositions. So, we can conclude that R. Kipling gave an objective glimpse of the British colonial rule in India as a real historical story-teller and a writer. His novel "Mother Maturin" wasn't lost but was further on restored in such narratives as: "Life's Handicap", "Plain Tales", "The House of Suddhoo", "The Gate of Hundred Sorrows", "The City of Dreadful Night", "Kim" and "To Be Filed For Reference", - to be contributed to the English literary heritage of this period. Kipling's acknowledgement of his occupation as journalistwriter is an acknowledgement of the market forces and commodity relations which characterise the literary scene in the late nineteenth century, so his strong desire to vividly show the pros and cons of the Indian and Anglo-Indian urban life in all its "unutterable horrors" was quite natural, dictated by the urgent issues of the time he portrayed. His mastership of the writer-journalist enables us to lead the further research into the reading-translation 
perspectives of R. Kipling's literary heritage unlike the colonial one. The postcolonial study could reveal the author's deep knowledge of the new gender relations, the position of women in society, of the human nature and traditions of Indian and Anglo-Indian society.

Concluding about the research on the translations and the role of the author in R. Kipling's prose and poetry, we can definitely state that with the help of tropes, language realias, deep historical, religious and philosophical insight, the acute knowledge of folklore and mythology, the writer, as a real cosmopolitan, managed to create the image of India with its wast and rich past and present, striving to get free from the British rule and its influence on the past and future of the growing new country. All this gives us grounds to change the traditional view of the writer as an orientalist one in the postcolonial critics to the cosmopolitan view. We can also follow the genesis of the interpretations of R. Kipling both among Ukrainian and Russian literary experts of translation and studies in literary theory, especially his major role in the dialogue between the two cultures of the East and West.

\section{References:}

1. Said E.W. Culture and Imperialism. L. : Vintage, 1994. 444 p.

2. Kipling R. Kim. London: Penguin Books, 1994. 287 p.

3. Стріха М. Кіплінг реальний і вигадани. Зарубіжна література. 1998. Ч. 41. С. 1-6

4. Герасимчук Л. Непричесані роздуми. Українська літературна газета. 2010. № 2(8). С. 2.

5. Suleri, Sara. The Rhetoric of English India. Chicago, 2012. 230 p.

6. R. Kipling's Verse Definite Edition. London : Hodder\&Stoughton, 1987. -845 p

\section{Диндаренко О. А. Р. КІПЛІНГ: КОСМОПОЛИТ ЧИ «БАРД ІМПЕРІАЛІЗМУ» В ПРОЗІ ТА ПОЕЗIÏ?}

Статтю присвячено темі розгляду повернених та всесвітньо відомих літературних творів P. Кіплінга, їх перегляду з точки зору літературознавства та ефективності впровадження нових варіантів їх перекладу та ідейно-філософського сприйняття. Зроблена спроба переглянути стереотипні погляди на творчість Р. Кіплінга як барда колоніальної епохи, на постколоніальні характеристики його як письменника-журналіста, який повідомляє про події в «гарячих точках планети», віщує нам про майбутнє. Автор представлений як журналіст, оповідач, який сміливо досліджує реалії місиевого життя з усіма його негараздами і недоліками, висміюючи і критикуючи при цьому «англо-індійський бомонд» із його міщанськими чеснотами і неповагою до місиевих, жсття яких представлено у найреалістичніших кольорах, без прикрашання, у самих його нетрях. Образ автора та оповідача максимально наближені одне до одного, щь особливо відчувається у їх спорідненості у переказі подій тих часів, фактів, культурних, філософських та релігійних особливостей Індійців, передані з майстерністю письменника-журналіста, спостерігача та мандрівия за вічними цінностями такого близького йому за духом Індійського народу. У таких творах, як «Повернення Імрея», «Тавро звіра», образ оповідача допомагає виявити походження дивних речей, що трапляються, щоб представити їх читацькому загалу. У "Дивній подорожі» та «Людині, якій судилося стати королем» автор із великою майстерністю відтворює надзвичайні події, віддаючи перевагу думиі читача, залишає остаточну думку за ним. У «Місті ста печалей» та «До вимоги» дослідження Р. Кіплінгом нічного життя близьких до нього кварталів може дати яскраві заголовки для жовтої преси про як життя місиевих, так $і$ колонізаторів. Виявляється, автор, як мозайку, складає картину низки подій, що складається з найважливіших його вражень почутого, побаченого, відчутого з першоджерела, що приваблює і привертає увагу читача, дає можливість створювати свою картину світу. Оповідач-мандрівещь Кіплінга з чужих картин життя складає свою правдиву історію, що надає можливість подальших перспектив дослідження творчості письменника з точки зору літературознавства і перекладу, відходячи від традиційних поглядів постколоніальної критики, представлених Е. Саїдом, С. Сулері та ін.

Для вдосконалення навичок перекладу з англійської мови, інтерпретачії текстів, для знавців зарубіжної літератури, а також для всіх охочих ознайомитися з особливостями новітніх поглядів на твори Р. Кіплінга пропонується дослідити відмінності та можливі перспективи розвитку філософських ідей письменника, які відображені в оригінальних текстах і перекладах робіт автора.

Ключові слова: космополіт, «залізний Рад'ярд», «бард імперіалізму», індійське та англо-індійське суспільство, орієнталізм, гендерна проблема, тендениї крос- $і$ мультикультуралізму, Британська імперія, постколоніальна література. 